\title{
PENGARUH INTENSITAS PENGGUNAAN MEDIA INTERNET TERHADAP PERILAKU BELAJAR SISWA
}

\author{
Saiful Haq \\ Guru Madrasah Aliyah Negeri, Purworejo \\ email: saifulhaq1410@gmail.com
}

\section{Abstract}

Internet has been exploited and used by students every day. Internet presence brings much convenience to users. However, the Internet also have a negative effect on students. In the negative effects arising from the use of the internet, the necessary countermeasures in order not to disrupt the learning activities of students. This study aims to determine the effect of Internet use on student learning behavior. This research is the primary data with quantitative approach. The number of samples used, there are 98 students of class XI MAN Purworejo. Samples were then given questionnaires that have been tested for validity and reliability. Analysis of the data used is descriptive analysis to determine the frequency, percentage, mean, median, and mode. The statistical test used was chi-square to determine whether there is the effect of Internet use on student learning behavior. The analysis showed that $50 \%$ of students are heavy users with an average of 1.77 hours per day usage. $31.6 \%$ of students open social media more than once a day. $45.9 \%$ Based on the learning behavior of students have learned good behavior. The findings of this study showed no effect of the use of the Internet by students' learning behavior ( $p=0.89$ ). The negative effect is felt most students is to forget the time. Ways to overcome them can Cognitive-behavioral Therapy.

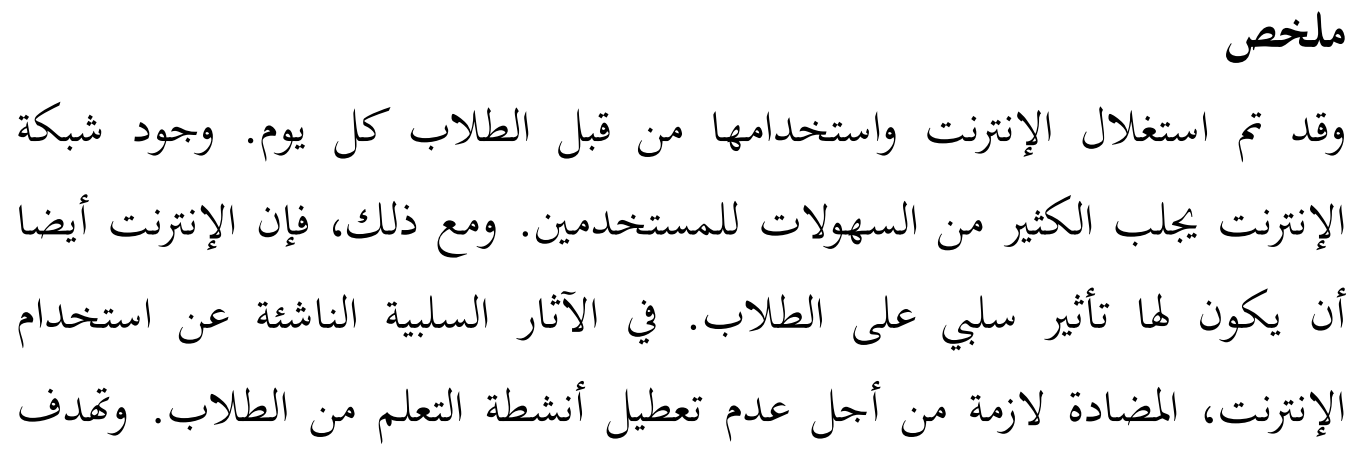


هذه الدراسة إلى تحديد أثر استخدام الإنترنت على سلوك تعلم الطلاب. هذا البحث

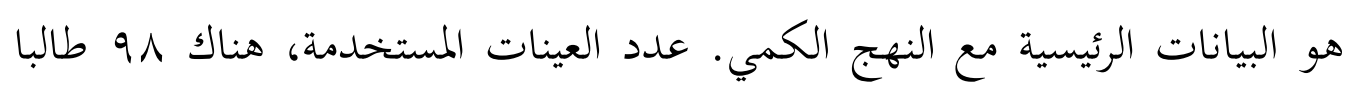

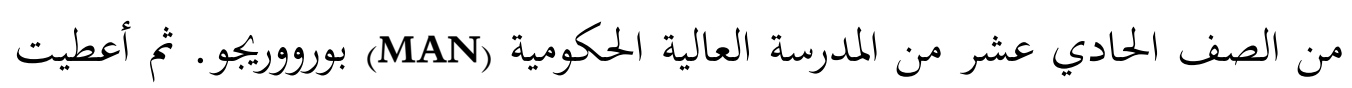

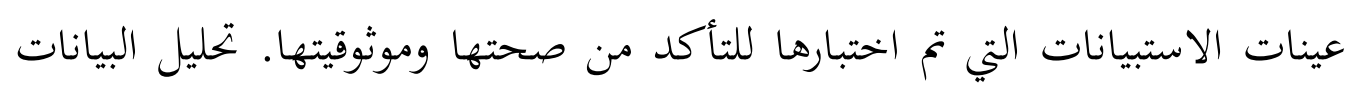
يستخدم التحليل الوصفي لتحديد الوتيرة والنسب المئوية والمتوسط والوسيط وواسطة.

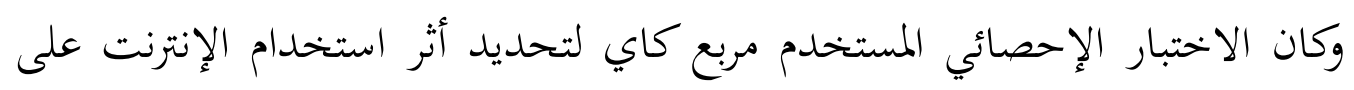

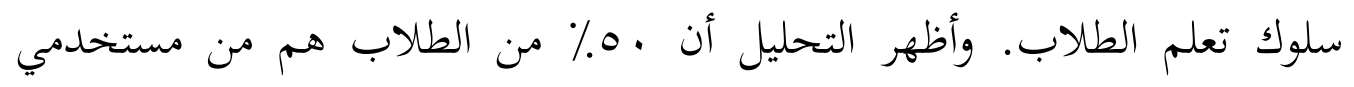

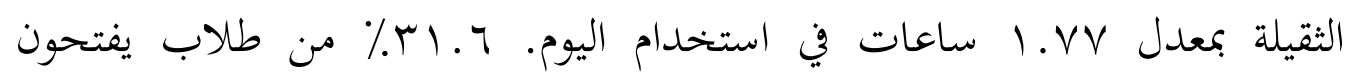

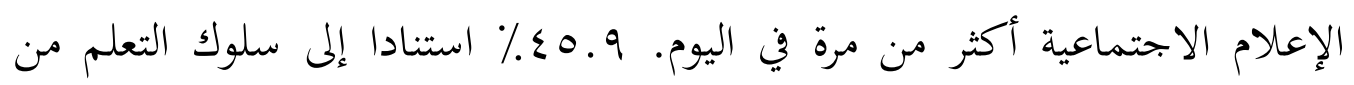

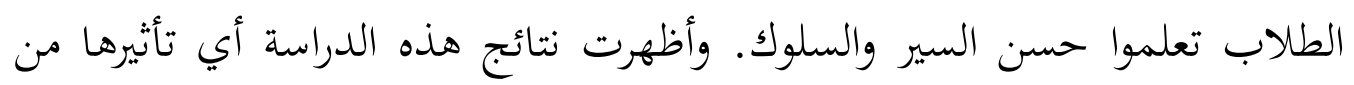
استخدام الإنترنت من قبل سلوك تعلم الطلاب (ع = 99. لمعظم الطلاب هو نسيان الوقت. يمكن سبل التغلب عليها بطريقة العلاج السلوكي

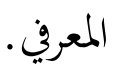

Keywords: Internet, Addiction, Perilaku, Belajar, Madrasah.

\section{A. Latar Belakang}

Dalam lingkungan pendidikan Islam maka kita mengenal lingkungan tarbiyah islamiyah yang di dalamnya terdapat ciri-ciri keislaman yang memungkinkan terselenggaranya pendidikan Islam dengan baik. Di dalam AlQuran tidak dikemukakan secara langsung mengenai lingkungan pendidikan Islam tersebut, akantetapi dalam sejarah, kegiatan pendidikanIslamberlangsung di rumah, masjid, sanggar para sastrawan, madrasah, dan universitas. Dalam perkembangannya, nyatanya pendidikan Islam tidak hanya dilakukan dalam lingkup lingkungan tersebut, melainkan dapat diakses dimana saja karena 
adanya teknologi berupa internet yang dapat menampung seluruh informasi baik informasi atau pengetahuan yang benar maupun yang salah.

Penggunaan internet sekarang ini menjadi rutinitas dalam masyarakat. Beberapa kelebihan penggunaan internet untuk memperoleh data dan informasi yang diperlukan oleh masyarakat menyebabkan penggunaan internet meningkat dari tahun ke tahun. Disamping ada kelebihannya, ada pula kekurangan dari penggunaan internet yang merupakan efek dari intensitas penggunaannya. Maka kekurangan yang tidak didambakan itulah perlu dilakukan penanggulangan agar tidak berlarut dalam keberlangsungan yang merugikan.

Menurut data statistik Asosiasi Penyelenggaraan Jasa Internet Indonesia (APJII) mengenai jumlah pengguna internet di Indonesia yang terus mengalami peningkatan cukup signifikan, mulai dari 512.000 di tahun 1998 menjadi 4,5 juta di tahun 2002. Bahkan dalam jangka waktu 5 tahun, yaitu pada akhir tahun 2007, jumlah meningkat mencapai angka 25 juta pengguna dan terus meningkat hingga tahun 2013 yang diproyeksi mencapai angka 82 juta pengguna ${ }^{1}$.

Keberadaan internet memang membawa begitu banyak kemudahan pada penggunanya. Berbagai macam informasi dan hiburan disediakan oleh internet. Hanya dengan menggunakan fasilitas situs pencari (search engine) dan mengetikkan kata kunci pada form yang disediakan, pengguna internet mendapatkan informasi yang diperlukan. Dengan fasilitas yang ditawarkan sosial media, pengguna dapat berkomunikasi dengan pengguna lain. Untuk mendapat hiburan, dapat menggunakan fasilitas penyedia video gratis maupun game online yang gratis. Begitu banyak hal yang didapat dari internet oleh siapapun, kapanpun, dan dimanapun. Menurut survei APJII tahun 2012, tujuan penggunaan internet $87,8 \%$ untuk mengakses jejaring sosial, seperti facebook, twitter, dan sebagainya. Selain mengakses jejaring sosial, pengguna juga menggunakan untuk mencari informasi (searching/browsing), mencari berita terkini $68,3 \%$, download/upload $62,1 \%$, dan sisanya untuk membuka email, chatting, game online, video call, blogging, file sharing, hingga jual beli². Dalam survei tersebut juga disebutkan bahwa pengguna internet di Indonesia

1 Asosiasi Penyelenggara Jasa Internet Indonesia (APJII), "Internet Users", diakses melalui http:/ / www.apjii.or.id/, pada 12 Juli 2013

2 Ibid. 
didominasi oleh pengguna yang berusia muda dengan rentang usia 12-34 tahun atau disebut dengan digital natives, yaitu generasi yang lahir dan hidup di era internet. Dengan persentase 30\% pengguna pada usia 20-34 tahun yang menggunakan komputer untuk bekerja dan 21,8\% pengguna dengan usia 12-19 tahun $^{3}$. Tidak seperti orang dewasa, remaja masih berada dalam masa transisi dimana mereka sangat mudah untuk menerima segala bentuk informasi dari media manapun. Remaja belum mampu untuk memilah hal-hal yang baik ataupun buruk dari internet.

Seperti negara lain, remaja di Indonesia khususnya yang mengenyam pendidikan tingkat Sekolah menengah Pertama (SMP) dan Sekolah Menengah Atas (SMA) dan sederajat, internet bukanlah hal yang asing lagi. Terlihat dari Survei yang dilakukan oleh Spire Research and Consulting yang bekerjasama dengan Majalah Marketing pada tahun 2008 mengenai tren dan kesukaan remaja Indonesia terhadap berbagai kategori dimana salah satunya adalah media. Hasil penelitian menunjukkan bahwa para remaja sudah mengerti dan menggunakan internet dalam kegiatan sehari-hari ${ }^{4}$.

Penggunaan media internet oleh pelajar tentunya mempengaruhi proses dan hasil pembelajarannya. Metode pengajaran dengan elektronik learning (e-learning) telah diterapkan pada beberapa instansi pendidikan pada berbagai mata pelajaran yang diajarkan. Dengan masuknya internet di dunia pendidikan dan sistem pendidikan yang mendukung penggunaan internet pada siswanya, misal untuk mencari materi tambahan yang tidak ada di buku ajar dan sifat dari pelajar yang notabene berada pada usia remaja, maka pengawasan terhadap penggunaan internet di kalangan pelajar ini harus diperhatikan.

Madrasah Aliyah Negeri (MAN) Purworejo merupakan salah satu instansi pendidikan dengan basis pendidikan agama Islam yang memiliki misi memanfaatkan perkembangan teknologi dan informasi dalam pengajarannya. Oleh karena itu siswa difasilitasi oleh sekolah maupun orang tua/wali siswa untuk memiliki komputer dan fasilitas internet. Walaupun demikian, MAN Purworejo tetap mengutamakan pendidikan akhlak pada siswa. Untuk itu, penelitian ini penting dilakukan karena dari penelitian ini dapat diketahui

3 Ibid.

4 Astutik Nur Qomariyah, "Perilaku Penggunaan Internet pada Kalangan Remaja di Perkotaan", dalam Jurnal Departemen Informasi dan Perpustakaan Fakultas Ilmu Sosial dan Ilmu Politik, Universitas Airlangga Surabaya terbit pada tahun 2009 
keadaan dan pengaruh intensitas penggunaan internet terhadap perilaku siswa di MAN Purworejo Tahun Pelajaran 2013/2014 karena ada beberapa kasus ditemukan dalam handphone dan laptop siswa gambar dan video porno. Hal ini memicu pertanyaan penelitian, apa dan bagaimana pengaruh penggunaan media internet bagi siswa MAN Purworejo terhadap perilaku belajar siswa.

\section{B. Metode Penelitian}

Penelitian ini merupakan penelitian primer dengan pendekatan kuantitatif dimana data yang dikumpulkan merupakan data numerik yang kemudian disusun, dijelaskan, dan dianalisis. ${ }^{5,6,7}$ Dengan menggunakan desain tersebut dapat dilihat bagaimana hubungan antar variabel pada satu waktu tertentu. Dengan pendekatan kuantitatif, dapat melihat kategori perilaku siswa dalam hubungannya dengan penggunaan internet dalam bentuk angka. Penelitian ini juga merupakan penelitian hubungan atau penelitian korelasi untuk mengetahui hubungan intensitas penggunaan internet terhadap perilaku belajar siswa.

Tempat penelitian dilakukan di MAN Purworejo Jl. Brigjen Katamso, Pangenjurutengah, Purworejo dengan ijin dari Kepala Sekolah MAN Purworejo. Peneliti melakukan penelitian dengan membagikan angket di kelas dengan bantuan guru yang sedang mengajar.

Populasi dalam penelitian ini adalah seluruh siswa MAN Purworejo TA 2013/2014. Sedangkan sampelnya adalah siswa kelas XI MAN Purworejo TA 2013/2014. Metode pengumpulan sampel dilakukan dengan simple random sampling dengan cara mengambil sampel secara acak tanpa pandang bulu sehingga semua anggota populasi memiliki kesempatan yang sama untuk terpilih menjadi anggota sampel ${ }^{8}$. Penentuan jumlah sampling minimal pada penelitian ini dihitung dengan

\footnotetext{
5 Margono, Metodologi Penelitian Pendidikan, (Jakarta: Rineka Cipta, 2004), hal.106

6 Winarno Surakhmad, Pengatar Peneltian Ilmiah, (Bandung: Tarsito, 2004), hal. 140

7 Sugiyono, Metode Penelitian Bisnis, (Bandung: Pusat Bahasa Depdiknas, 2003).

8 Moh Kasiram, Metodologi Penelitian Kuantitatif-Kualitatif, (Malang: UIN Maliki Press. 2010), hal. 260
} 
berdasarkan proporsi oleh $\operatorname{Slovin}^{9}$.yaitu

$$
n=\frac{N}{1+N e^{2}}
$$

Keterangan :

n : jumlah sampel

$\mathrm{N}$ : Ukuran Populasi

e : batas toleransi kesalahan (error tolerance)

Berdasarkan rumus di atas, maka dapat ditentukan jumlah sampel pada jumlah populasi 289 siswa adalah sebagai berikut:

$\mathrm{N}: 289$ siswa

e $: 0,1$

sehingga jumlah sampel menjadi

$$
\begin{aligned}
& n=\frac{289}{1+286(0.1)^{2}} \\
& R n=74,87 \approx 75
\end{aligned}
$$

Sehingga jumlah sampel minimal adalah 75 siswa. Dengan mempertimbangkan missing data, maka peneliti mengambil 100 siswa untuk dijadikan sampel dalam penelitian ini.

Teknik pengumpulan data yang digunakan adalah pengumpulan data primer. Pengumpulan data dilakukan dengan menggunakan instrumen yang telah dikembangkan dan diuji validitas dan reliabilitasnya. Peneliti mengambil data dengan bantuan dari guru pengajar setelah mendapatkan ijin dari sekolah. Kemudian guru pengajar memberikan angket tersebut kepada siswa terpilih.

\section{Hasil Penelitian}

Intensitas Penggunaan Internet pada Siswa Kelas XI MAN Purworejo Tahun Pelajaran 2013/2014. Dari hasil penelitian diperoleh bahwa ratarata siswa menggunakan internet selama 1,7 jam sekali pakai dengan waktu minimal siswa menggunakan internet selama seperempat jam dan terlama siswa menggunakan internet selama 5 jam dalam sekali penggunaan.

\footnotetext{
9 Consuelo G Sevilla. Research Methods, (Quezon City: Rex Printing Company, 2007).
} 
Frekuensi Penggunaan Internet pada Siswa Kelas XI MAN Purworeo Tahun Pelajaran 2013/2014. Sedangkan hasil analisis terhadap intensitas siswa dalam menggunakan internet 59,2\% siswa menggunakan internet lebih dari sekali sehari.Dari beberapa situs internet yang dibuka oleh siswa, sebanyak 31,6\% siswa membuka situs sosial media lebih dari sekali sehari.

Tempat Penggunaan Internet Siswa Kelas XI MAN Purworejo . Hasil analisis terhadap tempat penggunaan internet paling banyak siswa mengaku menggunakan internet di rumah, yaitu sebesar $67,3 \%$. Siswa juga menggunakan internet di warung internet, yaitu sebesar 45,9\%. Siswa juga mengaku menggunakan internet lewat handphone mereka sebesar 35,7\%. Adapula siswa yang menggunakan internet di sekolah dan di lain tempat seperti di rumah teman dan tidak ada siswa yang menggunakan internet di perpustakaan.

Berdasarkan pengakuan siswa yang dijawab dalam angket mengenai kebiasaan siswa dalam mengikuti pelajaran, umumnya siswa menjawab biasa hingga sering, yang artinya siswa tidak jarang dan cenderung seing untuk mengikuti pelajaran. Rata-rata terbesar diperoleh pada pernyataan mengenai mendengarkan penjelasan dari guru saat di ruang kelas dengan nilai ratarata 4,1 . Sedangkan rata-rata terendah diperoleh pada pernyataan mengenai membuat catatan atau pertanyaan dengan nilai rata-rata 2,8.

Pada pernyataan mengenai kebiasaan mendengarkan penjelasan dari guru, hampir sebagian siswa mengaku selalu mendengarkan (46,9\%) sedangkan pada pernyataan membuat catatan atau pertanyaan ada $42,9 \%$ siswa mengaku jarang melakukannya. 


\begin{tabular}{|c|c|c|c|c|c|c|c|c|c|c|}
\hline \multirow[t]{2}{*}{$\stackrel{\pi}{\geq}$} & $\circ^{\circ}$ & 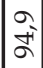 & $\stackrel{\circ}{i}$ & : & $\stackrel{0}{\circ}$ & $\stackrel{0}{-}$ & & $\stackrel{0}{-}$ & ㅇ. & : \\
\hline & $\approx$ & 2 & $\mathrm{~d}$ & 0 & - & - & & - & 0 & $\infty$ \\
\hline \multirow{2}{*}{ 营 $\frac{8}{2}$} & $\partial^{\circ}$ & $\begin{array}{l}0 \\
8 \\
10\end{array}$ & $\begin{array}{l}0 \\
\text { ते }\end{array}$ & हn' & ન & 둥 & & $\vec{c}$ & $\overrightarrow{n^{\prime}}$ & $\begin{array}{l}0 \\
8 \\
-1\end{array}$ \\
\hline & $\approx$ & F & নি & 10 & + & 10 & & $\infty$ & $\infty$ & $\propto$ \\
\hline \multirow{2}{*}{ 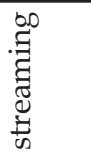 } & $\sigma^{\circ}$ & $\begin{array}{l}0 \\
8 \\
10\end{array}$ & $\begin{array}{l}0 \\
\text { cे } \\
\text { p. }\end{array}$ & $\therefore$ & $\overrightarrow{10}$ & $\vec{m}$ & & 采 & $\stackrel{0}{\circ}$ & 䢗 \\
\hline & $=$ & $\mathscr{F}$ & థি & $\wedge$ & Ln & $\infty$ & & +1 & 0 & $\infty$ \\
\hline \multirow{2}{*}{$\stackrel{8}{1}$} & $\partial^{\circ}$ & $\begin{array}{l}0 \\
0 \\
0\end{array}$ & $\stackrel{M}{\sim}$ & $\begin{array}{l}n \\
\mathbb{N} \\
\mathbb{N}\end{array}$ & ন̃ & $\stackrel{\text { N }}{=}$ & & 둥 & $\vec{m}$ & : \\
\hline & $\approx$ & $\stackrel{\sim}{\infty}$ & $\triangleq$ & $\stackrel{\sim}{N}$ & $a$ & $\Rightarrow$ & & 6 & $\infty$ & ஜ \\
\hline \multirow{2}{*}{ 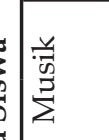 } & $\partial^{\circ}$ & $\stackrel{10}{\stackrel{1}{N}}$ & $\stackrel{m}{\underset{f}{*}}$ & 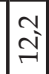 & $\begin{array}{l}\text { Na } \\
\text { ㄱ }\end{array}$ & 종 & & $\stackrel{N}{=}$ & $\begin{array}{l}+ \\
\infty \\
\infty\end{array}$ & : \\
\hline & $\approx$ & त̇ & $\nexists$ & $\approx$ & $\approx$ & $\triangle$ & & $\exists$ & $\stackrel{\infty}{\sim}$ & 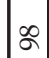 \\
\hline \multirow{2}{*}{ 苞 } & $0^{\circ}$ & $\stackrel{m}{\neq}$ & 弪 & $\mid \begin{array}{l}n \\
2 \\
n\end{array}$ & $\begin{array}{l}+ \\
\infty \\
\infty\end{array}$ & $\infty_{\infty}$ & & से & $\begin{array}{l}n \\
10 \\
10\end{array}$ & : \\
\hline & $=$ & 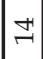 & 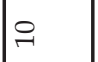 & $\stackrel{m}{\sim}$ & $\stackrel{\infty}{\sim}$ & $\infty$ & & సి & $\stackrel{20}{\sim}$ & 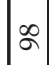 \\
\hline \multirow{2}{*}{\begin{tabular}{c|c}
0 \\
0 \\
0 \\
0 \\
0
\end{tabular}} & $0^{\circ}$ & $\mid \begin{array}{l}2 \\
1 \\
\xi\end{array}$ & 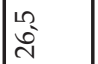 & $\left|\begin{array}{l}N \\
\infty\end{array}\right|$ & ๙ू & F & & है & $\stackrel{\circ}{\circ}$ & : \\
\hline & $\approx$ & ㄴ?又 & i & $\infty$ & $a$ & + & & $\infty$ & - & 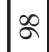 \\
\hline \multirow{2}{*}{3} & $0^{\circ}$ & $\vec{c}$ & $\vec{c}$ & $\begin{array}{l}m \\
0 \\
0\end{array}$ & $\begin{array}{l}\text { 오 } \\
\stackrel{2}{N}\end{array}$ & $\stackrel{m}{\stackrel{2}{-1}}$ & & $\begin{array}{l}+1 \\
\text { - }\end{array}$ & $\stackrel{+}{\infty}$ & $\begin{array}{l}0 \\
8 \\
8\end{array}$ \\
\hline & 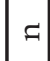 & $m$ & $\infty$ & $\stackrel{m}{\sim}$ & $\stackrel{\stackrel{2}{N}}{ }$ & $\approx$ & & 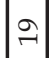 & $\stackrel{\infty}{\sim}$ & 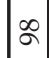 \\
\hline \multirow{2}{*}{ 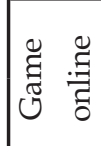 } & $0^{\circ}$ & $\begin{array}{l}\infty \\
\text { co } \\
\text { c. }\end{array}$ & $\begin{array}{l}\hat{\text { Aे }} \\
\text { ले }\end{array}$ & $\therefore$ & ๙̃ & $\vec{c}$ & & F & 등 & : \\
\hline & $\approx$ & के & ळ & $\triangle$ & $a$ & $\infty$ & & +1 & 0 & œ \\
\hline \multirow{2}{*}{ 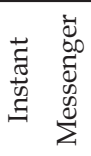 } & $\circ^{\circ}$ & $\begin{array}{l}0 \\
-1 \\
-1\end{array}$ & ते & Fَ' & 포 & F & & Na & 芯 & : \\
\hline & 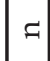 & $\overline{\text { ळ }}$ & $\vec{\sim}$ & 6 & $\curvearrowright$ & $H$ & & $a$ & ণి & $\infty$ \\
\hline \multirow{2}{*}{ 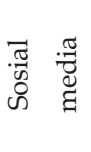 } & $\circ \circ$ & $\stackrel{0}{-}$ & in & $\mid \begin{array}{l}N \\
0 \\
-1\end{array}$ & $\begin{array}{l}+ \\
\infty \\
-\end{array}$ & $\begin{array}{l}2 \\
1 n^{2} \\
n^{2}\end{array}$ & & $\mid \begin{array}{l}+1 \\
\infty \\
\sim\end{array}$ & $\frac{0}{\vec{\infty}}$ & : \\
\hline & $f$ & - & 10 & 어 & $\stackrel{\infty}{\sim}$ & $\stackrel{\stackrel{2}{\sim}}{\sim}$ & & $\stackrel{\infty}{-}$ & ल & $\mathscr{2}$ \\
\hline \multicolumn{2}{|l|}{ 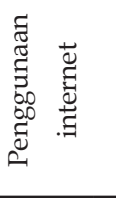 } & 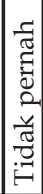 & 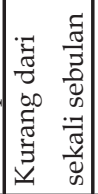 & 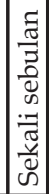 & 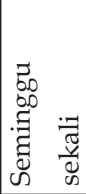 & 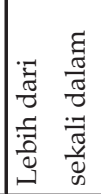 & 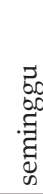 & 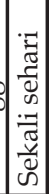 & 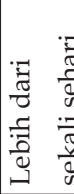 & 晃 \\
\hline
\end{tabular}


Membaca buku merupakan hal yang biasa dan cenderung sering dilakukan siswa. Hal ini terlihat dari perhitungan rata-rata mengenai kebiasaan membaca siswa biasa hingga sering. Rata-rata siswa terbanyak pada pernyataan mengenai memberi tanda pada bagian yang penting dengan nilai rata-rata 3,8. Sedangkan rata-rata terendah ditunjukkan pada pernyataan membaca buku teks lain selain yang disarankan dengan nilai rata-rata 2,7.

Dari hasil analisis perilaku belajar siswa berdasarkan kunjungan ke Perpustakaan menunjukkan jawaban paling banyak siswa mengaku jarang. Rata-rata tertinggi terdapat pada pernyataan memanfaatkan waktu luang dengan nilai rata-rata 2,9 sedangkan nilai terendah pada pernyataan meminjam buku saat berkunjung dan pernyataan ke perpustakaan secara teratur dengan nilai rata-rata 1,9 .

Lebih dari $50 \%$ siswa mengaku jarang perlahan membaca di perpustakaan $(60,2)$, meminjam buku setiap berkunjung $(59,2)$, dan ke perpustakaan secara teratur $(60,2 \%)$. Adapula yang tidak pernah berkunjung ke perpustakaan secara teratur sebanyak $27,6 \%$.

Berdasarkan hasil analisis terhadap perilaku belajar siswa berdasarkan kebiasaan siswa ketika akan meghadapi ujian atau ulangan kebanyakan siswa mengaku biasa hingga sering. Rata-rata terbanyak siswa mengaku banyak belajar sebelum ujian/ulangan dengan nilai rata-rata 3,8 dan nilai rata-rata terkecil ditunjukkan pada pernyataan gugup dan bingung sebelum ujian dengan rata-rata nilai 2,8 .

Untuk memudahkan analisis, pada variabel belajar dikategorikan menjadi dua kategori yaitu tidak baik dan baik. Pembagian dua kelompok tersebut dilakukan dengan cara menjumlahkan skor pada 4 sub variabel pengukur perilaku belajar siswa. Dari hasil perhitungan statistik didapatkan skor ratarata perilaku belajar siswa adalah 78,2. Dari nilai tersebut maka perilaku belajar siswa dibagi menjadi 2 kelompok yaitu siswa yang memiliki perilaku belajar yang baik (skor $>78$ ) dan kurang (skor $\leq 78$ ). Hasil perhitungan persentase didapatkan $45,9 \%$ siswa memiliki perilaku belajar yang baik. Dari hasil analisis dengan tabel silang diperoleh bahwa dari siswa yang sering menggunakan internet, 47,5\% nya memiliki perilaku belajar yang baik sedangkan pada siswa yang tidak sering menggunakan internet memiliki persentase $44,8 \%$ siswa. Hasil analisis menunjukkan nilai p-value lebih dari 0,05 hal ini menunjukkan 
bahwa tida ada pengaruh penggunaan internet terhadap perilaku belajar siswa kelas XI MAN Purworejo TA 2013/2014. (Tabel 3)

Tabel 2

Perilaku Belajar Siswa Berdasarkan Penggunaan Internet

\begin{tabular}{|c|c|c|c|c|c|c|c|c|c|}
\hline & \multicolumn{4}{|c|}{ perilaku belajar } & & & \multirow{3}{*}{$\begin{array}{c}\text { OR } \\
(95 \% \mathrm{CI})\end{array}$} & \multirow{3}{*}{ p-value } \\
\hline & & \multicolumn{2}{|c|}{ tidak baik } & \multicolumn{2}{|c|}{ baik } & \multicolumn{2}{|c|}{ TOTAL } & & \\
\hline & & $\mathrm{n}$ & $\%$ & $\mathrm{n}$ & $\%$ & $\mathrm{n}$ & $\%$ & & \\
\hline \multirow{2}{*}{$\begin{array}{l}\text { Penggunaan } \\
\text { internet }\end{array}$} & tidak sering & 32 & 55,2 & 26 & 44,8 & 58 & 100 & 1,11 & 0,89 \\
\hline & sering & 21 & 52,5 & 19 & 47,5 & 40 & 100 & $(0,5-2,5)$ & \\
\hline Jumlah & & 53 & 54,1 & 45 & 45,9 & 98 & 100 & & \\
\hline
\end{tabular}

Dari hasil analisis terhadap pengakuan siswa dalam angket mengenai pengaruh penggunaan internet pada siswa, maka terdapat hal negatif yang siswa rasakan dari penggunaan internet paling banyak menyebabkan lupa waktu (56\%).

Tabel 3

Daftar Pengaruh Negatif Penggunaan Internet Pada Siswa

\begin{tabular}{|c|l|c|}
\hline No & \multicolumn{1}{|c|}{ Masalah } & Persentase (\%) \\
\hline 1 & Lupa Waktu & 56 \\
\hline 2 & Pornografi & 38 \\
\hline 3 & Kecanduan & 36 \\
\hline 4 & Pemborosan & 32 \\
\hline 5 & Tindak Kriminal & 16 \\
\hline 6 & Gangguan Kesehatan & 10 \\
\hline
\end{tabular}

\section{Pembahasan dan Diskusi}

Menurut penelitian yang dilakukan oleh Badan Litbang SDM Kementerian Komunikasi dan Informasi bekerjasama dengan Badan Perserikatan BangsaBangsa (PBB) UNICEF mengenai Penggunaan Media Digital di Kalangan Anak dan Remaja di Indonesia menunjukkan bahwa sekitar 30juta anak dan remaja adalah pengguna internet dan terdapat kesenjangan antara daerah perkotaan dan pedesaan tentang pernah atau tidaknya menggunakan internet ${ }^{10}$. Dalam penelitian ini, semua siswa mengaku pernah menggunakan internet dan tidak

${ }^{10}$ Kemkominfo, "Siaran Pers Tentang Riset Kominfo dan UNICEF mengenai Perilaku Anak dan Remaja dalam Menggunakan internet" dalam Siaran Pers No.17/PIH/ KOMINFO/2/2014 pada 18 Februari 2014 diakses melalui http:kominfo.go.id pada 7 April 2014 pkl 09:20 WIB 
ada yang menyatakan tidak pernah menggunakan internet. Hal ini didukung kuat dengan adanya mata pelajaran teknologi informasi di MAN Purworejo yang didalam silabusnya terdapat materi mengenai penggunaan internet sehingga kemungkinan kecil siswa tidak menggunakan internet.

Penggunaan internet dalam penelitian ini dilihat dari dua aspek, yaitu intensitas penggunaan internet, yaitu waktu yang digunakan untuk menggunakan internet dan frekuensi penggunaan internet, yaitu seberapa sering dalam menggunakan internet. Dari hasil analisis diperoleh bahwa lebih dari 50\% siswa kelas XI menggunakan internet lebih dari sekali dalam sehari. Dengan demikian jika rata-siswa sekali menggunakan internet rata-rata 1,7 jam maka dalam sebulan siswa menggunakan internet selama 50 jam. Hal ini menyebabkan siswa termasuk dalam golongan heavy user ${ }^{11}$ yaitu penggunaan internet lebih dari 40 jam dalam 1 bulan. Golongan heavy user ini dapat dimasukkan dalam kelompok yang mengalami kecanduan internet.

Akan tetapi ada pula beberapa siswa yang menggunakan internet kurang dari 3 minggu sekali. Akan tetapi kecenderungan siswa tersebut kemudian menggunakan internet dalam waktu yang lama, mencapai 5 jam sekali pakai. Hal ini menunjukkan bahwa ada pula siswa yang termasuk dalam light user, yaitu penggunaan internet kurang dari 10 jam dalam satu bulan ${ }^{12}$. Walaupun demikian, rata-rata siswa menggunakan internet dalam sekali penggunaannya 1,7 jam atau sekitar 1 jam 45 menit. Sedangkan menurut penelitian yang dilakukan astutik terdapat perbedaan penggunaan internet pada remaja yang menggunakan internet di rumah dan di sekolah. Siswa yang menggunakan internet di sekolah, lama penggunaannya adala 1 hingga 2 jam dalam sekali penggunaan. Sedangkan pada remaja yang menggunakan internet di rumah waktu yang digunakan bisa 2 hingga 3 jam sekali penggunaan.

Pada analisis terhadap tempat siswa menggunakan internet, paling banyak siswa mengaku mengakses internet di rumah. Hal ini juga didukung oleh kebijakan sekolah dimana siswa tidak boleh membawa handphone ke sekolah dimana handphone merupakan salah satu fasilitas siswa untuk dapat mengakses internet. Selain itu, adanya kasus penemuan konten pornografi di

11 Yuyun W.I Surya, Pola Konsumsi dan Pengaruh Internet sebagai Media Komunikasi Interaktif pada Remaja (Studi Analisis Persepsi pada Remaja di Kotamadya Surabaya), (Surabaya: Lembaga Penelitian Universitas Airlangga, 2002).

12 Ibid. 
dalam handphone dan laptop menyebabkan adanya pembatasan penggunaan laptop di sekolah sehingga siswa lebih memilih untuk menggunakan internet di rumah.

Pada analisis terhadap penggunaan internet terhadap kepentingan penggunaan internet, siswa paling banyak mengaku menggunakan internet untuk media komunikasi, seperti dengan mengunjungi situs sosial media seperti facebook dan twitter dan menggunakan internet untuk chatting dengan blackberry messenger, aplikasi whatsapp dan we chat. Sedangkan fungsi lain, siswa menggunakan internet untuk browsing, baik untuk mencari informasi tentang pelajaran, biografi tokoh terkenal yang mereka gemari, dan untuk mengakses berita-berita terbaru. Ada uga yang mengaku menggunakan internet untuk online shopping atau belanja online.

Berdasarkan dimensi kepentingan penggunaan internet menurut Wayne Buente dan Alice Robin, yaitu kepentingan informasi, kesenangan, komunikasi, dan transaksi ${ }^{13}$, siswa telah menggunakan untuk ke empat dimensi kepentingan tersebut. Hal ini terlihat dari jawaban dalam angket pada pernyataan 5 situs yang sering dikunjungi. Akan tetapi memang hampir seluruh siswa membuka situs media sosial facebook dan twitter. Sedangkan untuk chatting, siswa menggunakan blackberry messenger, whatsapp, dan we chat.

Pada dimensi kepentingan informasi seperti mencari materi dan berita, siswa mengaku mencari dengan bantuan search engine seperti yahoo dan google. Adapula yang mencari berita dan informasi dari ask.com. Untuk memenuhi kebutuhan berita, siswa menggunakan detik.com, kaskus, kompas.com, dan beberapa situs lain yang lebih spesifik dengan frekuensi yang lebih kecil, misalnya ingin mengetahui berita tentang olahraga sepak bola maka akan mengunjungi situs bola.com atau untuk menambah berita musik dengan musik. com.

Banyak informasi yang bisa didapatkan melalui internet. akan tetapi, tidak semua informasi itu benar dn sesuai dengan teori yang ada dalam buku teks atau berita tidak sesuai dengan fakta yang terjadi di lapangan. Semua orang dengan segala kepentingan dapat memasukkan informasi di internet dan semua orang juga dapat mendapat informasi di internet sehingga diperlukan ketelitian

13 Wayne Buente dan Alice Robin, 2008, “Trendsin Internet Information Behavior, 2002004", dalam Journal of The American Society for Information Science, 2008. 
dalam memilih sumber-sumber informasi. Misalnya ketika memasukkan suatu kata kunci ke dalam google maka akan merujuk pada halaman-halaman yang mengandung kata kunci tersebut. Jika beruntung, kata kunci tersebut mengarahkan ke dalam artikel cendekia yang dimiliki oleh google. Biasanya berupa penelitian dari orang lain yang diupload ke artikel cendekia google.

Pada dimensi kepentingan kesenangan, banyak siswa menggunakan untuk menonton video melalui youtube.com atau mendengarkan musik dengan soundcloud. Siswa juga menggunakan internet untuk mengunduh lagu kesukaan mereka dengan bantuan dari mp3take.com. Adapula beberapa siswa yang bermain game online, akan tetapi dengan frekuensi dan intensitas yang jarang.

Pada dimensi kepentingan transaksi, hanya sedikit siswa yang menggunakan internet untuk online shopping. Sebagian siswa tidak pernah menggunakan internet untuk melakukan online shopping. Untuk siswa yang pernah melakukan online shopping atau hanya untuk mencari informasi harga, mereka menggunakan situs tokobagus.com.

Kemudian, dari hasil analisis rata-rata siswa memberi skor biasa dan sering untuk setiap point pernyataan. Untuk aspek perilaku siswa berdasarkan kebiasaan mengikuti pelajaran menunjukkan hal yang cukup baik. Artinya siswa cukup baik dalam mengikuti kegiatan belajar mengajar di dalam kelas. Minimal dengan mendengarkan penjelasan dari guru yang sedang mengajar. Hal tersebut juga merupakan salah satu bentuk penghargaan murid kepada guru yang sedang mengajar.

Untuk aspek kebiasaan membaca buku teks lain selain yang disarankan oleh guru, siswa jarang melakukannya. Hal ini didukung dengan sedikitnya persentase siswa yang mengaku mengunjungi perpustakaan sekolah. Peran buku teks lain dimungkinkan digantikan oleh internet dimana siswa dapat dengan mudah dan cepat mendapatkan informasi yang diinginkan. Misalnya, jika ada tugas untuk membuat makalah atau mencari pengertian suatu istilah, mencari proses terbentuknya reaksi kimia, atau mencari puisi karya seorang pujangga ternama, maka internet akan lebih mudah dan cepat menemukan informasi tersebut dibandingkan dengan mencari dalam buku. 
Tabel 4

Analisis Perilaku Belajar Siswa

\begin{tabular}{|c|c|c|c|c|c|c|c|c|c|c|c|c|}
\hline \multirow{2}{*}{ No } & \multirow{2}{*}{ Pernyataan } & \multicolumn{2}{|c|}{$\begin{array}{c}\text { Tidak } \\
\text { Pernah }\end{array}$} & \multicolumn{2}{|c|}{ Jarang } & \multicolumn{2}{|c|}{ Biasa } & \multicolumn{2}{|c|}{ Sering } & \multicolumn{2}{|c|}{ Selalu } & \multirow[t]{2}{*}{$\begin{array}{l}\text { rata- } \\
\text { rata }\end{array}$} \\
\hline & & $\mathrm{n}$ & $\%$ & $\mathrm{n}$ & $\%$ & $\mathrm{n}$ & $\%$ & $\mathrm{n}$ & $\%$ & $\mathrm{n}$ & $\%$ & \\
\hline \multicolumn{13}{|c|}{ Kebiasaan Mengikuti Pelajaran di Sekolah } \\
\hline 1 & $\begin{array}{l}\text { Memusatkan perhatian pada } \\
\text { materi }\end{array}$ & 3 & 3,1 & 12 & 12,2 & 30 & 30,6 & 40 & 40,8 & 13 & 13,3 & 3,5 \\
\hline 2 & Membuat catatan/ pertanyaan & 5 & 5,1 & 42 & 42,9 & 19 & 19,4 & 29 & 29,6 & 3 & 3,1 & 2,8 \\
\hline 3 & Mengerjakan latihan soal & 3 & 3,1 & 23 & 23,5 & 27 & 27,6 & 37 & 37,8 & 8 & 8,2 & 3,2 \\
\hline 4 & $\begin{array}{l}\text { Meminta penjelasan dari guru } \\
\text { tentang materi yang belum } \\
\text { dipahami }\end{array}$ & 4 & 4,1 & 33 & 33,7 & 31 & 31,6 & 21 & 21,4 & 9 & 9,2 & 3,0 \\
\hline 5 & Mengejar ketinggalan materi & 7 & 7,1 & 28 & 28,6 & 22 & 22,4 & 26 & 26,5 & 15 & 15,3 & 3,1 \\
\hline 6 & $\begin{array}{l}\text { Mendiskusikan materi yang } \\
\text { diberikan dengan teman }\end{array}$ & 2 & 2,0 & 16 & 16,3 & 23 & 23,5 & 34 & 34,7 & 23 & 23,5 & 3,6 \\
\hline 7 & $\begin{array}{l}\text { Mendengarkan penjelasan dari } \\
\text { guru }\end{array}$ & 0 & 0,0 & 5 & 5,1 & 19 & 19,4 & 28 & 28,6 & 46 & 46,9 & 4,1 \\
\hline 8 & $\begin{array}{l}\text { Dorongan untuk memenuhi } \\
\text { kewajiban (tugas/PR) }\end{array}$ & 3 & 3,1 & 10 & 10,2 & 29 & 29,6 & 34 & 34,7 & 22 & 22,4 & 3,6 \\
\hline \multicolumn{13}{|c|}{ Kebiasaan Membaca Buku Teks } \\
\hline 1 & $\begin{array}{l}\text { Mempersiapkan bahan sebelum } \\
\text { pelajaran }\end{array}$ & 1 & 1,0 & 22 & 22,4 & 22 & 19,4 & 22 & 22,4 & 34 & 34,7 & 3,7 \\
\hline 2 & Membaca sampai mengerti & 0 & 0,0 & 21 & 21,4 & 26 & 26,5 & 31 & 31,6 & 20 & 20,4 & 3,5 \\
\hline 3 & Memerhatikan kesehatan membaca & 6 & 6,1 & 25 & 25,5 & 37 & 37,8 & 15 & 15,3 & 15 & 15,3 & 3,1 \\
\hline 4 & Cara memahami bacaan & 1 & 1,0 & 13 & 13,3 & 35 & 35,7 & 33 & 33,7 & 16 & 16,3 & 3,5 \\
\hline 5 & $\begin{array}{l}\text { Memberi tanda pada bagian yang } \\
\text { penting }\end{array}$ & 2 & 2,0 & 10 & 10,2 & 21 & 21,4 & 34 & 34,7 & 31 & 31,6 & 3,8 \\
\hline 6 & Memusatkan perhatian & 2 & 2,0 & 8 & 8,2 & 28 & 28,6 & 37 & 37,8 & 23 & 23,5 & 3,7 \\
\hline 7 & Merasa harus membaca buku teks & 5 & 5,1 & 25 & 25,5 & 27 & 27,6 & 26 & 26,5 & 15 & 15,3 & 3,2 \\
\hline 8 & $\begin{array}{l}\text { Membaca buku teks lain selain } \\
\text { yang disarankan oleh guru }\end{array}$ & 6 & 6,1 & 45 & 45,9 & 24 & 24,5 & 18 & 18,4 & 5 & 5,1 & 2,7 \\
\hline \multicolumn{13}{|c|}{ Kunjungan Ke Perpustakaan } \\
\hline 1 & Memanfaatkan waktu luang & 5 & 5,1 & 39 & 39,8 & 25 & 25,5 & 19 & 19,4 & 10 & 10,2 & 2,9 \\
\hline 2 & $\begin{array}{l}\text { Berlahan membaca di } \\
\text { perpustakaan }\end{array}$ & 18 & 18,4 & 59 & 60,2 & 14 & 14,3 & 6 & 6,1 & 1 & 1,0 & 2,1 \\
\hline 3 & Meminjam buku setiap berkunjung & 28 & 28,6 & 58 & 59,2 & 9 & 9,2 & 3 & 3,1 & 0 & 0,0 & 1,9 \\
\hline 4 & Ke perpustakaan secara teratur & 27 & 27,6 & 59 & 60,2 & 9 & 9,2 & 3 & 3,1 & 0 & 0,0 & 1,9 \\
\hline 5 & $\begin{array}{l}\text { Meminjam buku ke perpustakaan } \\
\text { bila ada PR }\end{array}$ & 33 & 33,7 & 44 & 44,9 & 12 & 12,2 & 7 & 7,1 & 2 & 2,0 & 2,0 \\
\hline \multicolumn{13}{|c|}{ Kebiasaan Menghadapi Ujian atau Ulangan } \\
\hline 1 & Membuat catatan secara teratur & 6 & 6,1 & 22 & 22,4 & 20 & 20,4 & 26 & 26,5 & 24 & 24,5 & 3,4 \\
\hline 2 & Belajar teratur, baik, dan disiplin & 2 & 2,0 & 21 & 21,4 & 32 & 32,7 & 25 & 25,5 & 18 & 18,4 & 3,4 \\
\hline 3 & Suka atau tidak suka tetap belajar & 3 & 3,1 & 20 & 20,4 & 36 & 36,7 & 24 & 24,5 & 15 & 15,3 & 3,3 \\
\hline 4 & $\begin{array}{l}\text { Banyak belajar sebelum ulangan/ } \\
\text { ujian }\end{array}$ & 3 & 3,1 & 11 & 11,2 & 19 & 19,4 & 34 & 34,7 & 31 & 31,6 & 3,8 \\
\hline 5 & Gugup dan bingung sebelum ujian & 14 & 14,3 & 24 & 24,5 & 37 & 37,8 & 17 & 17,3 & 6 & 6,1 & 2,8 \\
\hline
\end{tabular}


Pada kebiasaan siswa mengunjungi perpustakaan, siswa jarang mengunjungi perpustakaan. Oleh sebab itu, persentase penggunaan internet di perpustakaan juga rendah karena siswa jarang mengunjungi perpustakaan. Jika dilihat dari ketersediaan buku di perpustakaan, jumlah buku pelajaran mencukupi untuk seluruh siswa.

Berdasarkan kondisi fisik bangunan pun kondisi perpustakaan MAN Purworejo yang berlokasi di Jalan Brigjen Katamso dalam keadaan baik. Akan tetapi kondisi perpustakaan di MAN Kartini (Lokasi 1) Kondisinya rusak. Hal ini memungkinkan siswa menjadi malas untuk ke perpustakaan karena menganggap kondisi perpustakaan pada saat mereka duduk di Kelas X dimana lokasi kelas X di MAN Kartini (Lokasi 1) sama dengan perpustakaan di MAN Kartini.

Untuk mengetahui penyebab rendahnya kunjungan siswa ke perpustakaan, diperlukan penelitian lebih mendalam mengapa siswa jarang menggunakan atau berkunjung ke perpustakaan madrasah.

Pada kebiasaan siswa ketika menghadapi ujian atau ulangan, siswa akan banyak belajar tentang materi yang akan diuji. Persaan gugup akan timbul jika siswa merasa belum siap untuk menghadapi ulangan tersebut. Ketika menghadapi ulangan/ujian suka atau tidak suka mereka harus belajar. Perbedaannya, jika ulangan atau ujian tersebut merupakan mata pelajaran yang disukai, maka siswa akan lebih giat dalam belajar atau lebih mudah memahami materi tersebut. Sehingga penggunaan internet kemungkinan akan mempengaruhi kebiasaan mereka ketika menghadapi ulangan ketika waktu yang digunakan untuk belajar dipotong untuk menggunakan internet sekedar membuka facebook, chatting dengan teman-teman melalui bbm, whatsapp, atau we chat, dan kegiatan melalui internet lainnya.

Untuk mempermudah dalam menganalisis, ke empat aspek tersebut dijumlahkan sehingga menghasilkan skor perilaku belajar. Semakin besar skor menunjukkan semakin baik perilaku belajarnya. Dari total skor, terlihat bahwa hampir 50\% siswa memiliki perilaku belajar yang baik artinya memiliki skor nilai di atas rata-rata total skor siswa. Hal ini menunjukkan perlunya peningkatan kebiasaan belajar yang baik pada siswa kelas XI MAN Purworejo.

Dalam penelitian ini, hasil analisis menunjukkan tidak ada hubungan yang signifikan antara penggunaan internet dengan perilaku belajar siswa kelas XI MAN Purworejo. Artinya penggunaan internet secara statistik tidak 
berpengaruh terhadap perilaku belajar. Akan tetapi, pertimbangan analisis lebih lanjut dengan mempertimbangkan faktor-faktor lain diperlukan. Tidak adanya analisis lebih lanjut dengan mempertimbangkan variabel-variabel lain sebagai variabel pengganggu dapat mempengaruhi hasil statistik.

Sesuai dengan teori yang disebutkan oleh Slameto, bahwa terdapat dua faktor yang mempengaruhi perilaku belajar, yaitu faktor dari diri siswa dan faktor yang berasal dari luar diri siswa sehingga jika dianalisis hanya satu variabel penggunaan internet saja mungkin tidak menunjukkan hasil yang signifikan akan pengaruh penggunaan internet terhadap perilaku belajar.

Pengaruh internet pada siswa memiliki dua sisi, positif dan negatif selama menggunakan internet. Hal ini dapat diketahui dengan pernyataan siswa dalam angket. Pada sisi positif, kebanyakan siswa terbantu dalam mengerjakan tugas sekolah yang diberikan dengan bantuan internet. Selain itu, siswa juga memperoleh informasi dan berita terbaru terkait hobi dan kegemaran mereka. Selain itu, internet juga digunakan siswa sebagai alat komunikasi dan silaturahmi dengan teman-teman. Adapula siswa yang mendapat manfaat dari adanya online shopping.

Akan tetapi, terlepas dari kegunanaan yang dirasakan siswa, adapula sisi negatif yang dirasakan siswa selama menggunakan internet. Kebanyakan dari siswa akan lupa waktu ketika menggunakan internet sehingga akan mengurangi waktu belajar siswa dan mengganggu konsentrasi. Adapula yang menyatakan menyebabkan lupa dan malas belajar, meskipun internet bukan satu-satunya penyebabnya. Yang paling parah, ada siswa yang menyatakan lupa akan ibadah, seperti lupa mengerjakan sholat atau menunda waktu sholat.

Sisi negatif lain dari penggunaan internet yang dialami siswa adalah pemborosan uang karena siswa membutuhkan biaya untuk mengisi pulsa modem atau untuk menggunakan internet di warung internet (warnet). Karena hanya sedikit siswa yang menggunakan internet di sekolah yang notabene adalah gratis, maka siswa membutuhkan biaya tambahan untuk membeli pulsa internet atau pulsa modem dan biaya untuk menggunakan internet di warnet, maka siswa banyak yang mengeluhkan adanya pemborosan. Misalnya biaya sebulan yang dibutuhkan untuk membeli pulsa internet unlimited salah satu penyedia layanan internet Rp 50.000,00 selama 1 bulan dengan kuota yang diberikan akan habis sebelum akhir bulan karena penggunaan yang berlebihan 
maka akan menambah biaya pembelian pulsa. Atau jika siswa menggunakan internet di warnet, dengan biaya Rp4.000,000 per jam, maka dala 1 bulan dengan penggunaan setiap hari libur dalam waktu sekali penggunaan 2 jam, maka akan menghabiskan biaya Rp4.000,00 × 2 jam x 8 hari maka hasilnya Rp64.000,00 perbulan.

Pengakuan lain yang diberikan siswa adalah munculnya iklan-iklan elektronik yang muncul di situs berita maupun di facebook dengan gambargambar porno yang menyebabkan secara tidak sengaja dilihat siswa. Padahal, siswa hampir setiap hari membuka situs facebook, berarti secara tidak langsung, siswa setiap hari juga melihat hal-hal berbau pornografi.

Hal lain yang patut menjadi perhatian adalah banyak siswa yang mengaku mengalami kecanduan, tergantung, dan ketagihan menggunakan internet. Padahal dampak keseringan menggunakan internet atau disebut online cukup banyak dan membahayakan, baik pada fisik maupun mental penggunanya. Menurut vemale. com $^{14}$, internet dapat menyebabkan gangguan kejiwaan:

1. Obsessive Compulsive Personality Disorder (OCPD) yaitu gangguan akibat keseringan mengakses internet yang menyebabkan seseorang sulit untuk berpikir rasional

2. Gangguan Kejiwaan Munchausen yaitu gangguan seseorang membuat kebohongan tentang dirinya untuk mendapat simpati dan rasa kasihan orang lain di dunia maya

3. Gangguan Kejiwaan Internet Asperger Syndrome yaitu perbedaan kepribadian antara di dunia maya dan di dunia nyata misalnya jika di internet terkenal dengan cerewet dan aktif sedangkan pada dunia nyata ketika bertemu langsung orang tersebut adalah orang yang pendiam.

4. Gangguan Kejiwaan Online Intermittent Explosive Disorder yaitu sikap mudah marah karena hal-hal yang remeh. Biasanya disebabkan oleh status dari temannya

5. Gangguan Kejiwaan Low Forum Frustation Tolerance yaitu sikap ingin dianggap penting dan apa yang dilakukan harus mendapatkan hasil seperti perkiraannya. Agar orang lain tahu kehebatannya maka dia akan memposting di internet dan mengeceknya setiap menit.

14 Vemale.com. "Suka Internetan? Hati-hati 5 Gangguan Jiwa Karena Keseringan Online" 4 Maret 2014 dalam http:/ / www.vemale.com, diakses pada 12 Mei 2014 
Sedangkan bahaya yang ditimbulkan akibat keseringan menggunakan internet pada fisik penggunanya adalah terjadinya gangguan pada syaraf pergelangan tangan akibat terlalu banyak mengetik yang menyebabkan adanya penekanan pada syaraf median ${ }^{15}$. Gangguan kesehatan pada mata juga sedikit disadari oleh siswa. Terlalu banyak menatap layar handphone atau komputer menyebabkan mata mudah lelah dan kering.

Bagaimanapun, internet memiliki sisi positif dimana siswa dapat mengetahui perkembangan informasi dan perkembangan terbaru dari dunia tentang berbagai hal sehingga dapat membuka wawasan. Akan tetapi, informasi yang diberikan di internet tidak selamanya benar, perlu pengawasan apakah informasi yang diberikan sesuai dengan teori yang diberikan sebelumnya, dan sesuai dengan kejadian atau fakta yang ada karena tidak semua sumber berita dan informasi dapat dipercayai dan benar adanya.

Berdasarkan pemahaman mengenai lingkungan tarbiyah islamiyah yang didalamnya terdapat ciri-ciri keislaman yang memungkinkan terselenggaranya pendidikan Islam dengan baik. Di dalam Al-quran tidak dikemukakan penjelasan mengenai lingkungan pendidikan Islam tersebut, kecuali lingkungan pendidikan yang dalam praktek sejarah digunakan sebagai tempat berlangsungnya kegiatan pendidikan yaitu, rumah, masjid, sanggar kegiatan para sastrawan, madrasah, dan universitas. Dalam Al-Quran sebagian dihubungkan dengan penduduknya yang buruk maupun yang baik dengan istilah Al-Qoryah. Lingkungan yang baik perlu dipertahankan dan lingkungan yang buruk perlu diperbaiki atau dihilangkan.

Dalam Al-quran surat Al-A'raf ayat 4 ditunjukkan dengan Al-qaryah, yang artinya "Berapa banyak negeri yang telah Kami binasakan, siksaan Kami datang (menimpa penduduk) nya pada malam hari atau pada saat mereka beristirahat pada siang hari" (QS. Al-A'raf ayat 4). Kemudian "... Mereka berdoa "Ya Tuhan kami, keluarkan kami dari negeri (Mekah) yang penduduknya zalim. Berilah kami pelindung dari sisi Mu, dan berilah kami penolong dari sisi Mu." (QS. An-Nisa Ayat 75)

Masa usia sekolah menengah (14-20 tahun) merupakan masa dimana siswa memasuki usia remaja dimana pertumbuhan fisik berkembang maksimal tetapi belum seimbang pada perkembangan psikologisnya. Oleh karena itu, dalam

15 Adelia Ratnadita. "Carpal Tunnel Syndrome, Saraf Terjepit di Pergelangan Tangan" 5 Januari 2012 dalam http:/ / health.detik.com, diakses pada 12 April 2014 
diri siswa sering terjadi konflik batin. Siswa masih labil dan mudah terpengaruh baik karena faktor dalam diri siswa maupun dari faktor luar siswa. Dalam masa ini siswa belum mengalami kemantapan batin kemana arah dan tujuan hidupnya.

Pendidikan moral dan pendidikan agama akan berperan dan berpengaruh penting pada diri siswa. Ajaran dari pendidikan moral dan pendidikan agama akan memberikan pengaruh dalam upaya mengatasi konflik dan gejolak batin yang dialami siswa dalam dirinya masing-masing. ${ }^{16}$

Pendidikan moral dan agama tentunya semata-mata tidak hanya dilakukan ketika mereka mencapai usia remaja. Melainkan pendidikan moral dan agama diberikan sejak anak masih berada dalam kandungan. Oleh sebab itu, peran orang tua dalam pendidikan moral dan agama sangat diperlukan dalam membentuk kepribadian anak.

Pada dasarnya, manusia membenci sesuatu yang berlawanan dengan tiga unsur kesucian yang paling utama, yaitu benar, baik, dan indah. Oleh karena itu, menurut fitrahnya, setiap manusia berusaha untuk menghindarkan dirinya dari perbuatan yang bertentangan dengan nilai-nilai kesucian, seperti melakukan sesuatu yang salah, buruk, dan jelek. Bila perbuatan itu dilakukan maka ia akan mengalami kegelisahan. Batinnya akan digugah oleh rasa bersalah (sense of guilty). ${ }^{17}$

Dalam penelitian ini, secara statistik menunjukkan tidak ada pengaruh antara intensitas penggunaan internet dengan perilaku belajar. Akan tetapi, dari hasil analisis pada angket berdasarkan jawaban dari siswa ketika diberi pertanyaan tentang dampak negatif yang ditimbulkan dari internet, sebagian besar siswa mengaku menggunakan internet menyebabkan lupa waktu, buang waktu, dan menyita waktu. Hal tersebut merupakan pernyataan yang paling banyak dialami oleh siswa. Selain itu adanya unsur pornografi pada iklan ketika membuka sebuah website, blog, ataupun media sosial juga dialami oleh siswa.

Berdasarkan hasil analisis dari peneliti, pengaruh negatif yang dianggap paling berpengaruh terhadap perilaku belajar siswa adalah penggunaan internet menyebabkan lupa waktu, termasuk waktu untuk belajar dan ibadah. Menyebabkan mereka cenderung malas untuk mengerjakan pekerjaan lain.

\footnotetext{
16 Jalaluddin, Teologi Pendidikan, (Jakarta: Raja Grafindo Persada, 2002), hal.146-147

17 Ibid, hal.156
} 
Hal ini menunjukkan adanya tanda-tanda kecanduan menggunakan internet (internet addiction). Menurut Dr. Young ${ }^{18}$ tanda bahaya kecanduan internet antara lain mengelak dan berbohong tentang berapa lama dan apa saja yang dilakukan di depan komputer, adanya perubahan pola tidur, seperti bangun pagi atau begadang hanya untuk online lebih lama, adanya permasalahan akademis seperti rangking menurun, adanya penarikan diri dari lingkungan sosial dan mengabaikan hobi yang dimiliki, serta mengalami penurunan nafsu makan. Hal tersebut merupakan tanda bahaya dari kecanduan internet sehingga perlu dilakukan pencegahan dini terhadap tanda bahaya tersebut sebelum siswa mengalami kecanduan yang sangat membahayakan untuk diri siswa sendiri.

Pada siswa yang memiliki orang tua yang belum sadar internet, jika sudah menunjukkan tanda-tanda kecanduan internet dapat dicegah dengan pendekatan Cognitive-Behaviour Therapy menurut Young ${ }^{19}$.

Mula-mula siswa diminta untuk mencatat seluruh aktivitas mereka ketika menggunakan internet. segala detail kegiatan seperti situs apa yang dibuka secara beruturan, lama waktu penggunaan internet, tempat mengakses internet, dan lain sebagainya dicatat dalam sebuah buku. Kemudian setelah dicatat dan mengetahui perilaku penggunaan internet, maka terapis dalam hal ini guru atau orang tua dapat membuat jadwal baru untuk sang anak dalam menggunakan internet, seperti anak dapat menggunakan internet pada pukul 4 sampai 5 sore saja. Kemudian setelah peraturan baru tersebut dilaksanakan kira-kira seminggu, dilakukan evaluasi apakah anak tersebut dapat menerapkan jadwal terbaru dan mencatat kesulitan yang dihadapi. Setelah itu, dilakukan pemecahan atau solusi untuk mengatasi kesulitan yang terjadi tersebut.

Dalam solusi tersebut dibutuhkan bantuan terapis ahli atau guru yang dapat mengatur murid. Akan lebih baik jika orang tua dapat menjadi terapis dari siswa tersebut karena sekaligus dapat memonitor dan mendekatkan hubungan antara anak dan orang tua.

Untuk siswa sendiri dibutuhkan penyuluhan tentang cara penggunaan internet yang baik dan benar, mencari sumber-sumber berita yang dapat

18 Kimberly Young, "Internet Addiction: Evaluation and Treatment", dalam Student British Medical Jornal, 1999.

19 Young KS. CBT-IA: The first treatment model for internet addiction. J Cogn Psychother, 2011. 
dipercaya dan tidak terlalu menggantungkan mendapatkan informasi dari internet. informasi tambahan mengenai kecanduan internet juga diperlukan. Dengan demikian siswa tahu apakah dia mengalami kecanduan internet atau tidak. Jika siswa tidak mengalami kecanduan, maka dia akan dapat menahan diri untuk tetap menggunakan internet sebelumnya atau jika siswa sudah mengalamikecanduaninternetyangmenyebabkanlupa waktu dan mengganggu jadwal belajar yang telah ditetapkan maka siswa dapat sedikit demi sedikit mengurangi kebiasaan terlalu sering dan lama dalam menggunakan internet.

Pada mulanya tugas mendidik adalah tugas orang tua. Akan tetapi karena perkembangan pengetahuan menjadi bertambahnya kebutuhan hidup, keterampilan, dan ilmu pengetahuan maka tugas orang tua dibantu oleh guru untuk mendidik anaknya sehingga terpenuhi kebutuhannya di masa yang akan datang. ${ }^{20}$ Oleh karena itu, saat ini sekolah menjadi solusi untuk membantu tugas orang tua mendidik anaknya.

Dalam keluarga yang dapat menggunakan internet, maka dapat digunakan beberapa cara menurut DR Kimberly Young ${ }^{21}$ seperti mengikuti perkembangan dan pengetahuan baru dalam iptek, berbicara dengan anak yang tentunya diperlukan pengetahuan tentang penggunaan internet agar pembicaraan tersambung, memahami kelebihan dan kekurangan dari internet, membuat peraturan pada anak dalam menggunakan internet, menyeimbangkan kapan waktu unuk online mengerjakan tugas dan kapan bermain dengan anak atau lingkungan sosial, menggunakan software kontrol untuk melacak situs-situs yang dibuka oleh anak di rumah, serta mendisiplinkan kebiasaan buruk orang tua agar tidak ditiru oleh anak. Hal tersebut merupakan saran untuk keluarga yang mengerti, memahami, dan dapat menggunakan internet. Sedangkan untuk keluarga yang tidak dapat menggunakan internet dapat sering bercengkerama dengan anak atau mendorong anak untuk memanfaatkan waktu luang untuk hal lain yang lebih bermanfaat dan memberikan dukungan pada anak akan hobi yang positif, seperti olahraga atau musik.

Belum ada bukti yang nyata untuk menanggulangi kecanduan internet. pendekatan perilaku dimungkinkan akan membantu. Tidak ada peran nyata

20 Ahmad Tafsir, Ilmu Pendidikan dalam Perspektif Islam, (Bandung: Remaja Rosdakarya, 1984), hal.74

${ }^{21}$ Ibid. 
dari penggunaan obat psikotropika. Terapi keluarga dan kerabat dimungkinkan dapat membantu penyelesaian masalah dan pada beberapa kasus kecanduan internet, penahanan diri pada penggunaan komputer dan akses internet dapat membantu mengatasi kecanduan. ${ }^{22}$

Dampak negatif yang diperoleh dari penggunaan internet sebenarnya dapat juga dilakukan dengan pengendalian diri untuk mencegah kecanduan internet yang dikhawatirkan dialami oleh siswa. Kontrol diri memungkinkan seorang pengguna internet bisa mengarahkan perilakunya secara tepat sehingga bisa menghindari dampak negatif yang ditimbulkan dari internet dan hanya mengambil sisi positif yang diberikan dari penggunaan internet.

\section{E. Penutup}

Kesimpulan yang dapat ditarik dari penelitian ini adalah intensitas penggunaan internet pada siswa kelas XI MAN Purworejo tahun pelajaran 2013/2014 menunjukkan 59,2\% siswa menggunakan internet lebih dari sekali sehari dengan rata-rata lama penggunaannya 1 sampai 2 jam. Kebanyakan siswa mengakses internet di rumah $(67,3 \%)$ yang juga menggunakan internet di warnet $(45,9 \%)$. Sedangkan pengaruh intensitas penggunaan internet terhadap perilaku belajar siswa kelas XI MAN Purworejo tahun pelajaran 2013/2014 menunjukkan tidak ada hubungan yang signifikan $(p=0,89)$.

Penanggulangan terhadap pengaruh negatif yang dirasakan siswa dalam menggunakan internet, yaitu menyebabkan lupa waktu adalah dengan menggunakan pendekatan Cognitive Behavior Therapy yang dapat digunakan untuk mengurangi ataupun mencegah dampak negatif dari penggunaan internet tersebut.

${ }^{22}$ Martha Shaw and Donald W. Black, "Internet Addiction: Definition, Assessment, Epidemiology and Clinical Management", jurnal CNS Drugs May 2008, Volume 22 Issue 5, pp 353-356 


\section{DAFTAR PUSTAKA}

Adri, Muhammad. 2003. "Pemanfaatan Internet sebagai Sumber Pembelajaran". IlmuKomputer.com

Al-Khalil abu al-Ainain. 1980. Falsafah al-Tarbiyah al Islamiyah fi al-Quran al Karim. Mesir: Dar al-Fikral al-'arabiyah

Arikunto, Suharsimi. 2006. Prosedur Penelitian untuk Pendekatan Praktik. Jakarta: Rineka Cipta.

Asosiasi Penyelenggara Jasa Internet Indonesia (APJII), "Internet Users", diakses melalui http://www.apjii.or.id.

Buente, Wayne dan Alice Robin. 2008. “Trends in Internet information Behavior: 2000-2004" , Journal of the American Society for Information Science.

Dell'Osso B, Hadley S, Allen A, Baker B. Chaplin WF, Hollander E. 2008, "Escitalopram in the treatment of impulsive-compulsive internet usage disorder: an openlabel trial followed by a double-blind discontinuation phase". J Clin Psychiatry.

Effendy dan Onong Uchjana. 2000. Ilmu, Teori, dan Filsafat Komunikasi. Bandung: Citra Aditya Bakti

Han DH, Hwang JW, Renshaw PF. 2010, “Bupropion sustained release treatment decreases craving for video games and cue-induced brain activity in patients with Internet video game addiction." Exp Clin Psychopharmacol 2010.

Hakim, Thursan . 2005. Belajar Secara Efektif. Jakarta: Puspa Swara Horrigan, John B. 2008. New Internet Users: What They Do Online, What They Don't, and Implications for The Net's Future dalam i http://www.pewinternet. org.

Jalaluddin. 2002. Teologi Pendidikan. Jakarta: Raja Grafindo Persada.

Kasiram, Moh. 2010. Metodologi Penelitian Kuantitatif-Kualitatif. Malang:UIN Maliki Press.

Kemkominfo. 2014. “Siaran Pers Tentang Riset Kominfo dan UNICEF mengenai Perilaku Anak dan Remaja dalam Menggunakan internet. Siaran Pers no.17/PIH/KOMINFO/2/2014 pada 18 Februari 2014 diakses melalui http:kominfo.go.id 
Ko, Chih Hung; Ju Yu Yen; Sue Hue Chen, et al. 2009. “Proposed Diagnostic Criteria and The Screening and Diagnosing Tool of Internet Addictiction in College Student" diunduh dari http:/ / search.proquest.com.

Margono. 2004. Metodologi Penelitian Pendidikan. Jakarta: Rineka Cipta.

Nata, Abudin. 1997. filsafat Pendidikan Islam 1. Jakarta:Logos Wacana Ilmu

Norman, F. A., \& Prichard, M. K.,1994, Cognitive Obstacles to the Learning of Calculus: A Kruketskiian Perspective. In Kaput, J. J. \& Dubinsky, E. (eds.) Research Issues in Undergraduate Mathematics Learning. Preliminary Analyses and Results, MAA Notes No 33, MAA.

Notoatmodjo, Soekidjo. 2003. Pendidikan dan Perilaku Kesehatan. Jakarta: Rineka Cipta

Oetomo dan Jarot Priyogutomo. 2004. "Kajian Terhadap Model e-Media dalam Pembangunan Sistem e-Education", makalah Seminar Nasional Informatika 2004 di Universitas Ahmad Dahlan Yogyakarta pada 21 Februari 2004

Qomariyah, Astutik Nur. 2009. "Perilaku Penggunaan Internet pada Kalangan Remaja di Perkotaan". Jurnal Departemen Informasi dan Perpustakaan Fakultas Ilmu Sosial dan Ilmu Politik. Surabaya: Universitas Airlangga Ramadhan, Arief . 2007. Seri Pelajaran Komputer Internet dan Aplikasinya. Jakarta:Elex Media Komputindo

Ratnadita, Adelia. “Carpal Tunnel Syndrome, Saraf Terjepit di Pergelangan Tangan" 5 Januari 2012 dalam http:/ / health.detik.com

Roberto, Frankie. 2002. "The Uses and Gratifications Model of the Media", dalam http:/ / news.bbc.co.uk

Rosenberg, Marc J. 2001. E-Learning: Strategies for Delivering Knowledge in the Digital Age. USA: The Mc Graw Hill Company.

Rosyidah. 2013. Pengaruh Media Facebook/Twitter terhadap Penyimpangan Perilaku Pada Siswa MTS Muhammadiyah 1 Mungkid Kabupaten Magelang, Yogyakarta: Thesis Fakultas Ilmu Agama Islam UII.

Sadirman. 2008. Interaksi dan Motivasi Belajar Mengajar. Jakarta: Rajawali Pers.

Sevilla, Consuelo G. 2007. Research Methods. Quezon City: Rex Printing Company

Shaw, Martha and Black, Donald W., 2008, "Internet Addiction: Definition, Assessment, Epidemiology and Clinical Management". Jurnal CNS Drugs, May 2008, Volume 22 Issue 5. 
Slameto. 2003. Belajar dan Faktor-Faktor yang Mempengaruhinya. Jakarta: Rineka Cipta

Soekartawi. 2003. "Prospek Pembelajaran Melaui Internet”. Bahan Ceramah/ Makalah pada Seminar dalam Muhammad Adri 2003

Surakhmad, Winarno. 2004. Pengatar Peneltian Ilmiah. Bandung: Tarsito.

Sugiyono. 2003. Metode Penelitian Bisnis. Bandung: Pusat Bahasa Depdiknas.

Suryabrata, Sumadi. 1983. Psikologi Pendidikan. Jakarta: Rajawali

Surya, Yuyun W. I. 2002. Pola Konsumsi dan Pengaruh Internet sebagai Media Komunikasi Interaktif pada Remaja (Studi Analisis) Persepsi pada Remaja di Kotamadya Surabaya, Surabaya: Laporan Lembaga Penelitian Universitas Airlangga Surabaya

Syah, Muhibbin. 1999. Psikologi Belajar. Jakarta: Logos Wacana Ilmu Utomo, Eko Priyo. 2007. Panduan Internet Untuk Pemula. Jakarta: MediaKom Vemale.com. "Suka Internetan? Hati-hati 5 Gangguan Jiwa Karena Keseringan Online" 4 Maret 2014 dalam http:/ / www.vemale.com

Widiyanto, Joko. 2012. SPSS For Windows. Surakarta: Badan Penerbit-FKIP Universitas Muhammadiyah Surakarta

Young, KS. 2011. “CBT-IA: the first treatment model for internet addiction". J Cogn Psychother. 
246 Millah Vol. XIV, No. 2, Februari 2015 